\title{
到津の森公園で研究する
}

\author{
外平友佳理 \\ 到津の森公園 ＝ 803-0065 北九州市小倉北区上到津 4-1-8
}

\section{Research at ITOZUNOMORI Zoological Park}

Yukari SOTOHIRA

ITOZUNOMORI Zoological Park, Kamiitozu,Kokurakita-ku,Kitakyushu 803-0065, Japan

\begin{abstract}
Zoo is an education and research center. Here we would like to introduce part of our research and to discuss what is "research" in the zoo? Two studies have been reported; (1) the test of hemagglutinaion inhibition antibody titiers of Newcastle disease in zoo bird, and (2) the soil bacterial flora analysis with genetical method. It is important to build internal and external cooperative relations for investigation research in the zoo. Although zoo veterinarians are required to do large variety of works, it needs to do the investigation research activities continuously for not only zoo field site but the public.

Key words : research at the ZOO, mission of ZOO, antibody titers of Newcastle disease, the soil bacterial flora analysis with genetical method.
\end{abstract}

Jpn. J.Zoo. Wildl.Med. 16 (1) : 19-22, 2010

\section{はじめに}

環境への意識がますます高まりつつあるなか，動物園は自然 保護や社会教育施設としての機能を有し, さらなる期待と可能 性に満ちている。遠藤秀紀氏はこれまで「研究する動物園」を テーマに本学会 3 大会にわたってシンポジウムや集会を行っ てきた。彼の熱くゆるぎない思いは動物園関係者に大きな意識 改革をもたらしている [1]。一方, 動物園で働く獣医師は獣 医診療業務のみならず, 幅広い分野で必要とされる職業である。 指定管理者制度が導入される中, 税金で養ってもらっていた時 代は今は昔,「収入なくして存続なし」という厳しい状況のなか, 動物園を支えている。

そうした中での「研究」とはいかなるものか。これまで当学 会でポスター発表を行った $2 つ の$ 事例をあげ, 客観的に改め て見直し，今後につなげて行きたい。
ニューカッスル病ウイルス保有状況とワクチン効果の研究 ニューカッスル病（ND）ウイルスは, 自然界に広く分布し, 多くの鳥類がND に対し感受性を示す [2]。養鵎分野ではワク チネーションプログラムが確立されているが, 動物園で飼育さ れている鳥類では確立されていない。当園では従来, ND 対策 として生ワクチンの飲水投与による予防を行っていたが, 確実 な投与が難しいことが難点であった。このため, 2002 年より 筋肉内投与により確実に投与できる ND 油性アジュバンド加不 活化ワクチン（以下，ND オイルワクチン）を用いた ND 対策 を実施した。

$\mathrm{ND}$ オイルワクチンは“京都微研” ND・OE ワクチン（京都微 研）を使用し，当園で飼養している全ての鳥類 43 種 134 羽を 対象に, 2002 年 1 月から 12 月にかけて, $0.5 \mathrm{ml} /$ 羽を胸部筋 肉内へ注射した。また, NDオイルワクチン接種前後において,

表 1 HI 測定結果

\begin{tabular}{|c|c|c|c|c|c|c|c|c|c|c|c|c|c|c|}
\hline \multirow{2}{*}{ 群 } & \multicolumn{12}{|c|}{ HI 抗体価（倍） } & \multirow{2}{*}{$\begin{array}{l}\text { 検査 } \\
\text { 羽数 }\end{array}$} & \multirow{2}{*}{$\begin{array}{l}\mathrm{GM} \\
\text { 平均 }\end{array}$} \\
\hline & $<2$ & 2 & 4 & 8 & 16 & 32 & 64 & 128 & 256 & 512 & 1,024 & $\geqq 2,048$ & & \\
\hline 前血清 & 0 & 2 & 9 & 4 & 0 & 0 & 0 & 0 & 0 & 0 & 0 & 0 & 15 & 4 \\
\hline 後血清 & 0 & 0 & 0 & 0 & 1 & 2 & 1 & 3 & 2 & 1 & 2 & 3 & 15 & 244 \\
\hline 接種前のみ & 0 & 3 & 9 & 6 & 1 & 0 & 1 & 0 & 2 & 0 & 0 & 0 & 22 & 8 \\
\hline 接種後のみ & 0 & 0 & 1 & 0 & 0 & 0 & 2 & 2 & 7 & 1 & 4 & 8 & 25 & 458 \\
\hline
\end{tabular}


血清中の ND-HI 抗体価の比較検討を行った。採血については, 10 種 15羽はNDワクチン接種前と接種後 (40日〜 11 か月後), 13 種 21 羽は接種前のみ, 18 種 25 羽は接種後 (25 日〜 11 か月後）の多実施した。なお, ND-HI 抗体検査は, 福岡県北九 州家畜保健衛生所（現福岡県北部家畜保健衛生所）に依頼した。 その結果, 同一個体で前後血清が得られた 15 羽については, 前血清が幾何平均（GM）值 4 倍に対し, 後血清が GM 值 244 倍と，抗体価の有意な上昇が認められた。また，前血清のみ 採血した 22 羽の GM 值は 8 倍, 後血清のみ採血した 25 羽の GM 值は 458 倍であり, 接種後の個体の方が有意に高かった。 一般に ND を防御するためには 20 倍以上の抗体価が必要とい われており，このワクチネーションはNDの防御に有効であっ たと考えられた。

\section{網羅的な土袞細菌叢の調査}

動物園はZZONOSIS の観点から, 従業員のみならず来園者 にも感染症対策が必要な環境にあり, まれではあるが職員や来 園者への感染事例が報告されている $[3,4,5]$ 。しかし実際には, その環境を微生物学的視点から調査した報告はそれまでなかっ た。このため, 到津の森公園内の土壌について, 計 19 か所の 土壌細菌叢を, 土壌より抽出した DNA を用い, $16 \mathrm{~S}$ rRNA 遺 伝子の塩基配列を決定するといった, 遺伝子工学的手法によっ て網羅的に土壌細菌叢を産業医科大学医学部微生物学教室とと
もに調査した。

全菌数をエチジウムブロマイド蛍光染色法により調べた結 果, 一般的に言われている $10^{8} \sim 10^{9}$ 個 (/g 土壌) の数の範 囲内であり, 好気性菌の割合もこれまで報告されているものと 同様で, 培養可能な菌は全菌数の $1 / 10 \sim 1 / 100$ の範囲内で あった [6]。菌の種類は生体試料の結果に比べ菌叢が多様で, 科 (Family) レベルで $26 \sim 29$ 種類と, 動物展示施設以外の 土壌と同様の傾向がみられた [6]。また, 一類〜四類感染症 に銘記されている病原菌は検出されなかった。また，ノウサギ が急死した場所の, 消毒後の土壌の菌叢を, 消毒剂を噴霧して いない土壌と比較した結果, 明らかに異なる菌叢になっていた。 これは, 消毒剤が土袞表面の菌を殺菌し, 土壌菌叢が変わった と考えられた。

\section{それぞれの研究から得たもの}

ND 抗体検査までの経緯は, 他の動物園獣医師からの情報か ら端を発しており,「同業者との情報の共有とネットワーク」 は非常に大切な「初めの 1 歩」である。そして, 管轄の家畜 保健衛生所に抗体検査を行っていただけたことは，パートナー シップの重要性を感じる。さらに言うまでもなく職場内の協 力が何よりも必要不可欠なものであり, 趣旨を理解し, 根気強 く付き合っていただいた飼育職員の存在なくしえてはあり得な かったものである。こうして得られた結果は今日まで生かされ，

表 2 人と動物に関する菌

\begin{tabular}{|c|c|c|c|c|c|c|c|c|c|c|c|c|}
\hline \multirow{3}{*}{ 菌属 } & \multicolumn{12}{|c|}{ サンプル名 } \\
\hline & \multicolumn{2}{|c|}{ バードケージ } & \multicolumn{3}{|c|}{ ふれあい広場 } & \multirow{2}{*}{$\begin{array}{l}\text { パタスモ } \\
\text { ンキー }\end{array}$} & \multirow{2}{*}{$\begin{array}{l}\text { キリンと } \\
\text { シマウマ }\end{array}$} & \multirow{2}{*}{$\begin{array}{l}\text { フラミ } \\
\text { ンゴ }\end{array}$} & \multirow{2}{*}{ ゾウ } & \multirow{2}{*}{$\begin{array}{l}\text { チンパ } \\
\text { ンジー }\end{array}$} & \multirow{2}{*}{$\begin{array}{c}\text { マンド } \\
\text { リル }\end{array}$} & \multirow{2}{*}{$\begin{array}{l}\text { シロムネ } \\
\text { オオハシ }\end{array}$} \\
\hline & 入り口 & 奥 & ヤギ & モルモット & ロロバ & & & & & & & \\
\hline Pseudomona 属 & $0.6 \% *$ & $1.2 \%$ & & & $1.1 \%$ & & & & $2.3 \%$ & & & $1.1 \%$ \\
\hline Legionella 属 & & & & & & & & & & & & $1.1 \%$ \\
\hline Stenotrophomonas 属 & $0.6 \%$ & & & & & & & & & & & $3.3 \%$ \\
\hline Enterococcus 属 & & & & & & & & & & $1.1 \%$ & & \\
\hline Brucella 属 & & & & & & & & & & & & $2.2 \%$ \\
\hline Burkholderia 属 & $1.7 \%$ & & $1.2 \%$ & & & $1.1 \%$ & & $1.1 \%$ & & $2.2 \%$ & $1.1 \%$ & \\
\hline Bacillus 属 & $0.6 \&$ & & & $2.2 \%$ & $7.7 \%$ & & $3.3 \%$ & $1.1 \%$ & & & $2.3 \%$ & \\
\hline Clostridium 属 & $1.7 \%$ & $1.2 \%$ & $2.4 \%$ & & $1.1 \%$ & $1.1 \%$ & $1.1 \%$ & & & & & $3.3 \%$ \\
\hline Nocardia 属 & & & & & & & & $1.1 \%$ & & & & \\
\hline Bacteroides 属 & & & & & & & $1.1 \%$ & & & & & \\
\hline \multicolumn{13}{|l|}{ Mycobacterium 属 } \\
\hline Corynebacterium 属 & & & & & & & & & $1.1 \%$ & & & \\
\hline Rhodococcus 属 & & & & & & & & & & $1.1 \%$ & $1.1 \%$ & \\
\hline 検出された属の種類 & 69 & 41 & 32 & 41 & 41 & 55 & 42 & 47 & 41 & 36 & 47 & 43 \\
\hline
\end{tabular}


新着個体の導入時には必ず ND オイルワクチンの接種を続けて いる。また結果を公開することで, 他の関係者にも科学的根拠 をもって伝えることができるようになった。

土袞細菌叢の検査では, 感染症法の 1 類〜 4 類に銘記され たものが, 優占的に存在しないことが分かり, 人と動物の共通 感染症が増えつつあるなかで, 動物展示施設は何があるか分か らない, という漠然とした不安を取り除く 1 つの証明ができ たと思われる。さらに，消毒の前後で検査を行ったことで，消 毒薬の効果を把握することができた。加えて興味深かったこと は, 消毒後に菌種は変化したが, 全体の菌数やバラエティはほ とんどかわらなかったことや, 土袞にこれほど多様な菌叢があ ることを実際に把握できた。獣医師として細菌は悪者とみなす 癖があるが, 細菌も自然の一部であるという認識が生まれ, 広 い視野に立って見ることができるようになった。これらも，や はり, 人と人のつながりで成り立っており, 産業医をはじめ大 学機関との綿密な連携に尽きる。そして, このような基礎デー タの蓄積は, 今後動物展示施設における感染危険性を予測する うえで重要な資料となり, 感染症対策上ハイリスクな職場で事 故が起きた場合の感染経路の推定, 消毒薬散布後の消毒薬効果 の評価においても有用であることが分かった。

研究することの意義はたくさんあるが，それが必ず「現場ひ いては社会に確実に生かされること」が最も重要な目標である と考えている。

\section{これからも研究するために}

冒頭で述べたように，動物園で働く獣医師としては多岐にわ たる任務を背負っているなか, 研究することは, 獣医師として の本来の業務に必要なものであり, 豊かな知識と経験が得られ 今後も業務に生かされていくものである。研究するためには現 場職員各個人の意識改革が最も重要であるが, そこに付随して 研究パートナーや職場へ理解を得るための説明交渉能力なども 必要であり, それがなければ, 研究ができないことを周りのせ いにしてしまうといった悲劇が起こる。止まめ不況の嵐と少子 化の波が迫りつつある今, 動物園や水族館を取り巻く環境は必 ずしも明るいものではない。けれども同じ意識をもつた仲間と 手を取り合い前に進むことで，少しずつでも確実に成果をあげ ていくことができると信じている。日々堆積する貴重なデータ を有効に活用することは相当な労力と精神力が必要とされ, と もすれば見送りがちとなってしまうが，例えば「期限を決めて 結果を出すと公言する」など自らを追い达む工夫などして打開 していきたい。実際に大会での講演をきっかけとして, 8年経っ た現在のN D 抗体価の保有状況調査を始めている。

日々野生動物たちと接する幸せを自分のもので終わるのでは なく, 彼らの不思議, 魅力, その奥の深さを研究しその結果を 伝えることが使命である以上，貴重な職業につけた実感と感謝 を胸に, そして何より, 研究を通じて多くの方々の協力と絆に

表 2（続き）

\begin{tabular}{|c|c|c|c|c|c|c|}
\hline \multicolumn{5}{|c|}{ ノウサギ展示場 } & \multicolumn{2}{|c|}{ 広場 } \\
\hline 古死亡個体 & ○死亡個体 & 死亡場所消毒後 & 入り口 & 外 & 中 & 斜面 \\
\hline \multirow[t]{3}{*}{$1.1 \%$} & & & & $1.2 \%$ & & \\
\hline & $1.1 \%$ & & & & & \\
\hline & $1.1 \%$ & $1.1 \%$ & $1.3 \%$ & & & \\
\hline \multirow[t]{2}{*}{$5.6 \%$} & & $3.2 \%$ & & $10.5 \%$ & $3.3 \%$ & $3.4 \%$ \\
\hline & & $1.1 \%$ & & $0.0 \%$ & $1.1 \%$ & $1.1 \%$ \\
\hline \multirow[t]{2}{*}{$2.2 \%$} & $1.1 \%$ & $5.3 \%$ & $1.3 \%$ & $5.8 \%$ & $1.1 \%$ & $3.4 \%$ \\
\hline & & $1.1 \%$ & & & & \\
\hline \multicolumn{7}{|l|}{$2.2 \%$} \\
\hline & & & & & $1.1 \%$ & \\
\hline 44 & 50 & 51 & 41 & 29 & 42 & 45 \\
\hline
\end{tabular}


感謝して,これからも研究を行っていきたい。

\section{要}

約

動物園が研究施設としての役割も担う以上, 獣医師に求めら れることは多くある。ND 抗体価測定調查や展示場内の網羅的 な土壌細菌叢検査などの研究活動を行ってきたが, 今後もさら なる持続的な調査研究活動が求められている。

キーワード：動物園での研究，動物園の役割，ND-HI 抗体価， 土壌細菌叢遺伝子検査

\section{引用文 献}

1. 遠藤秀紀.2009. 社会教育機関での研究の可能性.日本野生動物医学会 誌 14: 19-25

2. 䳕病研究会編. 2006. 鳥の病気第 6版, pp.10-13. 鷄病研究会, つくば.
3. 田原研司, 板垣朝夫, 新田則之, 村下 伯, 足立行, 道越小雪, 福士秀人, 中島一敏, 松井珠乃, 大山卓昭, 岡部信彦, 小川基彦, 岸本寿男, 松本 明. 2002. 鳥展示施設に関連したオウム病集団発生事例一島根県松江市. 病 原微生物検出情報 23: 247-248.

4. 和栗 敦, 桜庭 恵, 澤田 譲, 阿部幸一, 工藤美子, 齋藤和子, 田中 純, 大西 基喜. 2007. 牧場での「ふれあい体験」が感染源と示唆される腸管出血 性大腸菌 O157 感染事例一青森県. 病原微生物検出情報 28: 116-118.

5. 八柳 潤, 齊藤志保子, 今野貴之, 山脇徳美, 斉藤健司, 三浦 鐵晃. 2007. ふれあい動物イベントが原因とされた腸管出血性大腸菌集団感染事例の 概要一秋田県：病原微生物検出情報 28: 198-200.

6. 谷口初美, 福田和正, 王 岩, 樋上光雄, 山内和紀, 市原剛志, 水野康平, 石松維代, 世良暢之, 濱崎光宏, 高橋浩司, 堀川和美. 2004. 土壤細菌叢 評価表の構築一廃棄物処分場の硫化水素ガス発生対策のために一。産業 医科大学雑誌 26: 349-367. 